In the present edition the revision might well have been more vigorous. Caecal stasis and ileal kink could now be deleted and so give valuable space for such conditions as Crohn's disease. Congenital stricture of the pharynx might likewise give way to congenital atresia of the oesophagus, a condition now amenable to surgical intervention. The time has also come for the inclusion of a chapter on the diagnosis of surgical disease of the chest. However these criticisms in no way detract from the excellence of a book which will continue to lay sound foundations in clinical diagnosis.

S.F.T.

\section{A TEXTBOOK OF MENTAL DEFICIENGY (AMENTIA)}

By A. F. Tredgold, M.D., F.R.C.P., F.R.S.(Ed.). 7 th Edition. Baillière, Tindall $\&$ Cox. London. 1947. Pp. xvi + 534. Price 3os.

'The publication of the seventh edition of this excellent work will be welcomed by all those concerned with the clinical and social aspects of mental deficiency. Dr. Tredgold's book is undoubtedly the most complete and valuable textbook on this subject available. Clinical, psychometric, social and legal aspects of mental deficiency are described with great clarity by a psychiatrist of great distinction. It is fortunate that a textbook of this quality is available at a time when the recognition and assessment of the milder degrees of intellectual deficiency are realized to be of great importance, not only for many problems of clinical medicine, but also for those of sociology and forensic psychiatry. The seventh edition includes a number of new illustrations which maintain the excellent standards of former editions. The Education Act of 1944 resulted in a number of alterations of the law related to the identification and education of the subnormal child and the new edition brings up to date the account of the legal requirements at the present time. The book can be recommended unreservedly to psychiatrists, to all doctors concerned with social medicine, to school medical officers and to anyone interested in acquiring a wider and deeper knowledge of the human organism.

D.H.

\section{THE METABCLIC BRAIN DISEASES AND THEIR TREATMENT}

By G. Tayleur Stockings, M.B., B.S., D.P.M. Baillière, 'Tindall \& Cox. London. 1947. Pp. viii +262 . Price $16 s$.

The author, struck by the success of the empirical methods of physical treatment current in psychiatry, has attempted a new classification of psychiatric disorders based on his views of how such treatments bring about their results. Thus, the effective disand the catatonias which respond to "anoxic therapy' (convulsant therapy) become the 'dysoxic' disorders and the schizophrenias which ' respond only to hypoglycaemic therapy' become the 'dysglycic' disorders. This naive play with words might be forgiven if the weight of experimental evidence demonstrated any disorder of the oxidation mechanisms in the first group or of the glycolytic mechanisms of the brain in the second. So far such evidence is almost lacking. But the author is not content with this. He assumes that anoxia is the effective factor in convulsant therapy despite the large amount of evidence to the contrary. No reference in the book is made to perhaps the most extensive and thorough review of this subject by Gellhorn in 1943, which contains the evidence against anoxia as the effective agent. In the case of the 'dysglycic' disorders, hypoglycaemia of course produces a profound anoxia of the cortex. Moreover the 'shock' treatments-convulsant and hypoglycaemic, have in common one factor which is neither alteration of the oxygen nor glucose uptake of the brain after treatment, but alteration of autonomic activity, particularly of the sympathetic-adrenal system. It seems a pity that the author has undertaken this book without familiarizing himself with most of the significant literature on his subject.

D.H.

\section{HANDBOOK OF PRACTICAL BACTERIOLOGY}

By T. J. Mackie, G.B.E., M.D., D.P.H., and J. E. MCCARTNEY, M.D., D.Sc. 8th Edition. E. \& S. Livingstone Ltd.,'Edinburgh. I 948. Pp. 624. Price 25s.

The latest edition of this admirable book fully maintains the very high reputation that its predecessors have enjoyed for many years.

The book has been completely revised and considerable improvements have been made in the arrangement of the text. Useful new data and methods resulting from the latest developments in bacteriological knowledge and technique have been incorporated. In particular may be cited additions to those sections dealing with the biology of microorganisms, electron microscopy, the use, care and sterilization of syringes, enrichment and selective media, and spirochaetal and virus infections. It has also been found possible to omit from the latest edition some material which experience has shown to be of lesser importance or value.

This edition contains somewhat fewer pages than its predecessor, though the expansion of the text has involved a slight overall increase in the dimensions of the book. It nevertheless still remains very convenient to handle.

The book is to be strongly recommended to students, technicians and routine bacteriologists alike, and in fact, must be considered to be an indispensable item in the equipment of the bacteriological laboratory.

S.

\section{POGKET GYNAEGOLOGY}

By S. G. Clayton, M.D., M.S., F.R.C.S., M.R.C.O.G. J. \& A. Churchill, 'Ltd. 1948. Pp. I 12. Price 7s. 6d.

The Pocket Series of J. \& A. Churchill, Ltd., has been increased by the publication of this new 